\title{
Stability of bioactive compounds in minimally processed beet according to the cooking methods
}

\author{
Juliana Arruda RAMOS ${ }^{1 *}$, Karina Aparecida FURLANETO ${ }^{1}$, Giovanna Alencar LUNDGREN ${ }^{1}$, \\ Flávia Aparecida de Carvalho MARIANO-NASSER ${ }^{1}$, Veridiana Zocoler MENDONÇA ${ }^{1}$, \\ Maurício Dominguez NASSER ${ }^{1}$, Rogério Lopes VIEITES ${ }^{1}$
}

\begin{abstract}
The current study aimed to determine the functional propriety of fresh beets under different cooking methods through the quantification of bioactives compounds. Beets were chosen for uniformity of size, color and absence of defects. They were thoroughly washed in running water to remove dirt, manually peeled with a knife, sliced through a stainless-steel food processor ( $5 \mathrm{~mm}$ slicing disc) and submitted to four different cooking methods: steaming, pressure, oven-baked and hot-water immersion. Analysis were performed in both uncooked and cooked beets to evaluate antioxidant activity, total phenolic content, carotenoids, flavonoids and betalains. The experiment was completely randomized design (CRD). Data were subjected to analysis of variance (F test) and means were compared by Tukey test $(\mathrm{p}<0.05)$. Oven-baked beets preserve most of the bioactive coumpouds, maintaining better levels of carotenoids, flavonoids, betacyanin and betaxanthin than the other cooking methods. The antioxidant activity was similar between the treatments, except in the pressure. Moreover, different cooking methods did not affect phenolic compounds concentration in beets.
\end{abstract}

Keywords: Beta vulgaris L.; antioxidants; betalains.

Practical Application: Bioactive compounds of minimally processed beet in different cooking methods.

\section{Introduction}

In addition to providing important nutrients, vegetables have functional compounds that favor organic functions, bringing health benefits and lower disease risk (Del-Vechio et al., 2005; Carvalho et al., 2006). In this way, the interest in studying the stability of bioactive compounds (Campos et al., 2008).

In cooking, those methods that transfer heat; high temperatures; cooking for a long period and different cooking techniques are responsible for chemical and physical changes that may affect nutritional value of food (Scheibler et al. 2010).

The betalains are colored nitrogenous pigments, soluble in water and responsible for the dark red color of the beets. It has a function similar to anthocyanins, however never appears together this pigment (Schiozer \& Barata, 2007).

Beets are the main source of betalains, which is an important natural antioxidant. Studies indicate that betalain potentially inhibits lipid oxidation and cholesterol synthesis, as well as skin and lung cancer in rats (Volp et al., 2009). Betalains also show antiviral and antimicrobial activities (Lila, 2004). Therefore, studies have shown free radical antioxidant power of beet, which is among the top ten most potent antioxidants found in nature to date (Volp et al., 2009).

It is known that cooking induces significant changes in physicochemical properties and structural characteristics of the food; therefore, different results are achieved at various time and temperature by destroying enzymes/microorganism and affecting sensory/nutritional properties. Cooking also disaggregates plant structures since both palatability and digestibility become better. All these changes are influenced by heat transfer, temperature intensity, duration and cooking methods applied (Alves et al., 2011).

Given all the above, the current study aimed to determine the nutritional properties of minimally processed beets under different cooking methods through the quantification of bioactive compounds.

\section{Materials and methods}

The hybrid Borus cultivar was used, purchased at the following geographical coordinates: $21^{\circ} 35^{\prime} 45^{\prime \prime}$ and $46^{\circ} 53^{\prime} 23^{\prime \prime} \mathrm{W}$. Subsequently, beetroots were selected for uniformity of size, color and absence of defects. They were then washed thoroughly in running water to remove dirt.

Afterwards, tuberous roots were manually peeled with a knife and sliced into a stainless-steel food processor ( $5 \mathrm{~mm}$ slicing disk) and submitted to four cooking methods: steaming, pressure cooking, oven-baked and immersion in hot water. With regards to the oven-baked method, it took 15 minutes to preheat the oven to $200^{\circ} \mathrm{C}$, sliced beetroots were wrapped in aluminium foil 
to cook evenly, as well as avoiding excessive dehydration. In the other methods, beets were placed in boiling water.

All cooking methods expressed in Table 1 were tested before the experiment began to establish the correct cooking time until beets were "al dente" (Copetti et al., 2010).

Once cooked, the samples were immediately frozen in liquid nitrogen; then macerated and kept in a freezer for biochemical analysis.

The extract used for the analysis of antioxidant activity and total phenolic compounds was made with ethanol and water extractor (70:30), using ultrasonic bath (20 min) and centrifuged, $6000 \mathrm{rpm}$ (50 $\mathrm{min})$. The following analysis were performed: antioxidant activity was measured by DPPH (Mensor et al., 2001), expressed as reduction of \%DPPH; total phenolic content was determined by Folin-Ciocalteau's spectrophotometric method (Singleton et al., 1999), expressed in mg of gallic acid $100 \mathrm{~g}^{-1}$ sample. Carotenoid content was determined, as described by Linder (1974), expressed in $\mathrm{mg} 100 \mathrm{~g}^{-1}$ of beetroot.

Flavonoids were determined by the spectrophotometric method adapted from Santos \& Blatt (1998), $0.1 \mathrm{~g}$ of sample was weighed, $4 \mathrm{ml}$ of acidified methanol solution was added, homogenized and placed in an ultrasonic bath for 30 minutes, $1 \mathrm{ml}$ of $5 \%$ aluminium chloride solution in methanol was added and left to stand in the dark for 30 minutes; afterwards, it was centrifugated for 20 minutes in $6000 \mathrm{~g}$ and read in a spectrophotometer at $425 \mathrm{~nm}$, results in $\mathrm{mg}$ of rutin $100 \mathrm{~g}^{-1}$.

Betalain content was determined, as described by Stintzing et al. (2005) adapted, expressed in $\mathrm{mg} 100 \mathrm{~g}^{-1}$. It was weighed around $1 \mathrm{~g}$ of sample using extractor of water and ethanol (1:1), passing through shaking and centrifugation, then the supernatant was mixed with buffer solution (Mcllvaine) and then spectrophotometric reading. The calculation used was: BLC $[\mathrm{mg} / \mathrm{L}]=[(\operatorname{AxDFxMWx1000}) /(\operatorname{ex1})]$, where $\mathrm{A}$ is the maximum absorption value corrected for reading at $600 \mathrm{~nm}$; DF is the dilution factor and 1 is the optical path of the cuvette $(1 \mathrm{~cm}), \mathrm{MW}$ is the molar mass, and is the molar coefficient of

Table 1. Time used for each cooking method.

\begin{tabular}{cc}
\hline Cooking method & Time in minutes \\
\hline Steaming & 30 \\
Pressure cooking & 10 \\
Oven-baked & 40 \\
Hot-water immersion & 24 \\
\hline
\end{tabular}

molar extinction. The total content of betalamin was the sum of betaxanthines and betacyanins.

The experiment was completely randomized design (CRD), with three repetitions. Data were subjected to analysis of variance (F test) and means were compared by Tukey test $(\mathrm{p}<0.05)$.

\section{Results and discussion}

In general, oven-baked method was the best procedure to preserve bioactive compounds in beetroots (Table 2), probably, since there was an indirect contact of beets with the heat, which leads to food dehydration and total solids concentration (Ornellas, 2007). In pressure cooking, beets presented lower levels of carotenoids, flavonoids and betalains, mainly due to the direct contact of beets with water, as the temperature increased, the water approached its boiling condition and evaporated; therefore, an increase in the pressure of a closed system will increase evaporation of water molecules and raise the temperature (109-111 $\left.{ }^{\circ} \mathrm{C}\right)($ Dal Bosco \& Conde, 2013).

Monreal et al. (2009) studied the influence of cooking methods on antioxidant activity in vegetables, showed that beet kept its antioxidant capacity in various cooking and quantification methods, such result corroborates with that one found in the current study. Another research was conducted with two cooking methods (i.e. steaming and microwave) in broccoli, such study indicated no statically significance in the antioxidant capacity of cooked and uncooked vegetable in both methods (Zhang \& Hamauzu, 2004). In plant tissues, heat exposure damages affect antioxidant compounds (Lin \& Chang, 2005).

Another study indicated that phenolic compounds concentration increased in pepper, broccoli and green beans; but decreased in peas, pumpkin and leeks (Turkmen et al., 2005); therefore, the authors stated that phenolic compounds may be freer during cooking, that is, its content decreased by rearrangement. However, there was no significant difference in phenolic compounds concentration between uncooked and cooked beets in the current study.

Oven-baked method was the procedure that best-preserved carotenoid content in beets, followed by steaming and immersion in hot water, but these both did not present any statistical difference between them; while pressure-cooking performed the highest loss. However, steamed carrots have presented the highest loss of carotenoids in another study (Miglio et al., 2008). Furthermore, some researchers claim contradictory results in carotenoids content under different cooking methods (Maia et al., 2008).

Table 2. Total antioxidant activity (TAA \%), phenolic compounds (PC mg of gallic acid/100 $\mathrm{g}^{-1}$ ), carotenoids (CT mg $\left.100 \mathrm{~g}^{-1}\right)$, flavonoids (FV mg of rutin $100 \mathrm{~g} \mathrm{~g}^{-1}$ ), betacyanin (BTCY mg $100 \mathrm{~g} \mathrm{~g}^{-1}$ ), betaxanthin (BTXT mg $100 \mathrm{~g}^{-1}$ ), betalain (BTL $\mathrm{mg} 100 \mathrm{~g}^{-1}$ ), under different cooking methods.

\begin{tabular}{|c|c|c|c|c|c|c|c|}
\hline Cooking & TAA & $\mathrm{PC}$ & $\mathrm{CT}$ & $\mathrm{FV}$ & BTCY & BTXT & BTL \\
\hline Steaming & $52.63 \mathrm{ab}^{*}$ & $94.41 \mathrm{a}$ & $0.68 \mathrm{bc}$ & $174.56 \mathrm{~b}$ & $30.59 \mathrm{ab}$ & $20.88 \mathrm{ab}$ & $51.48 \mathrm{a}$ \\
\hline Pressure cooking & $28.05 \mathrm{~b}$ & $59.22 \mathrm{a}$ & $0.38 \mathrm{c}$ & $63.19 \mathrm{c}$ & $12.40 \mathrm{c}$ & $8.09 \mathrm{~d}$ & $20.48 c$ \\
\hline Oven-baked & $66.48 \mathrm{a}$ & $96.94 \mathrm{a}$ & $0.94 \mathrm{ab}$ & $267.64 \mathrm{a}$ & $35.49 \mathrm{a}$ & $25.34 \mathrm{a}$ & $60.83 \mathrm{a}$ \\
\hline Hot-water immersion & $53.41 \mathrm{ab}$ & $65.91 \mathrm{a}$ & $0.61 \mathrm{bc}$ & $149.50 \mathrm{~b}$ & $21.37 \mathrm{bc}$ & $14.67 \mathrm{c}$ & $36.04 \mathrm{~b}$ \\
\hline Uncooked & $57.63 \mathrm{a}$ & $77.81 \mathrm{a}$ & $1.31 \mathrm{a}$ & $290.64 \mathrm{a}$ & $31.63 \mathrm{a}$ & $17.88 \mathrm{bc}$ & $49.51 \mathrm{ab}$ \\
\hline $\mathrm{CV} \%$ & 18.40 & 34.18 & 22.4 & 16.92 & 13.84 & 10.97 & 1265 \\
\hline
\end{tabular}

${ }^{*}$ Means followed by equal letters in the column do not differ from each other by the Tukey test $(\mathrm{p}<0.05)$. 
Regarding to flavonoids content, there was no statistically difference in oven-baked carrots and uncooked. However, there was significant reduction among other methods, such as hot-water immersion, steaming and pressure cooking, whose flavonoids reduction was of $78.2 \%$ at the end. In a study conducted with broccoli in hot-water immersion, there was a decrease in flavonoid concentration (50\%) when compared to uncooked broccoli; the current study highlights a similar result (Pellegrini et al., 2010).

Betalains concentration, which is the sum of betacyanin and betaxanthin, in steamed beets did not differ from uncooked and oven-baked beets; since there was an indirect contact of beetroots with water when submitted to steaming and baking methods. Additionally, steam moisturizes the food and slows down the fibers, as well as enhancing appearance and reducing losses in hot-water immersion caused by water-soluble vitamins, minerals and bioactive compounds due to surface coagulation (Dal Bosco \& Conde, 2013).

Picoli et al. (2010) found betalain contents between 13 and $23 \mathrm{mg} 100 \mathrm{~g}^{-1}$ in minimally processed fresh beets, such values are lower than those found in the current study. Probably, due to the beetroots in different cut thickness and contact surface, as they cut $2 \mathrm{~mm}$ thick. In accordance with Vitti et al. (2003), pigments extravasation during food preparation and/or pigments degradative processes that occur soon after minimal processing are probably due to lower thickness, as they presented greater contact surface to the ambient lighting; which resulted in greater pigment degradation. In a study with beet and betalain stability, Drunkler et al. (2006), reported that the pigment formation was found to be highly influenced by environmental conditions, since the absence of light resulted in greater stability of these compounds.

\section{Conclusions}

Oven-baked beets preserve most of the bioactive coumpouds, maintaining better levels of carotenoids, flavonoids, betacyanin and betaxanthin than the other cooking methods. The antioxidant activity was similar between the treatments, except in the pressure. Moreover, different cooking methods did not affect phenolic compounds concentration in beets.

\section{References}

Alves, N. E. G., Paula, L. R., Cunha, A. C., Amaral, C. A. A., \& Freitas, M. T. (2011). Efeito dos diferentes métodos de cocção sobre os teores de nutrientes em brócolis (Brassica oleracea L. var. italica). Revista do Instituto Adolfo Lutz, 70(4), 507-513.

Campos, F. M., Martino, H. S. D., Sabarense, C. M. \& Pinheiro-Sant`Ana, H. M. (2008). Estabilidade de compostos antioxidantes em hortaliças processadas: uma revisão. Alimentos e Nutrição, 19(4), 481-490.

Carvalho, P. G. B., Machado, C. M. M., Moretti, C. L., \& Fonseca, M. E. N. (2006). Hortaliças como alimentos funcionais. Horticultura Brasileira, 24(4), 397-404. http://dx.doi.org/10.1590/S010205362006000400001.

Copetti, C., Oliveira, V. R., \& Kirinus, P. (2010). Avaliação da redução de potássio em hortaliças submetidas a diferentes métodos de cocção para possível utilização na dietoterapia renal. Revista de Nutrição, 23(5), 831-838. http://dx.doi.org/10.1590/S1415-52732010000500013.
Dal Bosco, S. M., \& Conde, S. R. (2013). Nutrição e saúde. Lajeado: Univates.

Del-Vechio, G., Corrêa, A. D., Abreu, C. M. P., \& Santos, C. D. (2005). Efeito do tratamento térmico em sementes de abóboras (Cucurbita ssp) sobre os níveis de fatores antinutricionais e/ou tóxicos. Ciência e Agrotecnologia, 29(2), 369-376. http://dx.doi.org/10.1590/S141370542005000200014.

Drunkler, D. A., Fett, R., \& Luiz, M. T. B. (2006). Avaliação da estabilidade de betalaínas em extrato de beterraba (Beta vulgaris L.) com $\alpha-, \beta$ - e $\gamma$ - ciclodextrinas 1. Boletim CEPPA, 24(1), 259-276.

Lila, M. A. (2004). Plant pigments and human health. In S. Davis (Ed.), Plant pigments and their manipulation (chap. 3, pp. 248-274). Oxford: CRC Press.

Lin, C. H., \& Chang, C. Y. (2005). Textural change and antioxidant properties of broccoli under different cooking treatments. Food Chemistry, 90(1), 9-15. http://dx.doi.org/10.1016/j.foodchem.2004.02.053.

Linder, S. (1974). A proposal for the use of stardadized methods for chlorophyll determinations in ecological and ecophysiological investigations. Physiologia Plantarum, 32(2), 154-156. http://dx.doi. org/10.1111/j.1399-3054.1974.tb03743.x.

Maia, G. E. G., Pasqui, S. C., Lima, A. S., \& Campos, F. M. (2008). Determinação dos teores de vitamina $\mathrm{C}$ em hortaliças minimamente processadas. Alimentos e Nutrição, 19(3), 329-335.

Mensor, L. L., Menezes, F. S., Leitão, G. G., Reis, A. S., Santos, T. C., Coube, C. S., \& Leitão, S. G. (2001). Screening of Brazilian plant extracts for antioxidant activity by the use of DPPH free radical method. Phytotherapy Research, 15(2), 127-130. PMid:11268111. http://dx.doi.org/10.1002/ptr.687.

Miglio, C., Chiavaro, E., Visconti, A., Fogliano, V., \& Pellegrini, N. (2008). Effects of different cooking methods on nutritional and phsysicochemical characteristics of selected vegetables. Journal of Agricultural and Food Chemistry, 56(1), 139-147. PMid:18069785. http://dx.doi.org/10.1021/jf072304b.

Monreal, A. M. J., Diz, L. G., Tomé, M. M., Mariscal, M., \& Murcial, M. A. (2009). Influence of cooking methods on antioxidant activity of vegetables. Journal of Food Science, 74(3), 97-103. PMid:19397724. http://dx.doi.org/10.1111/j.1750-3841.2009.01091.x.

Ornellas, L. H. (2007). Técnica dietética: seleção e preparo de alimentos (8. ed). São Paulo: Atheneu.

Pellegrini, N., Chiavaro, E., Gardana, C., Mazzeo, T., Contino, D., Gallo, M., Riso, P., Fogliano, V., \& Porrini, M. (2010). Effect of diferent cooking methods on color, phytochemical concentration, and antioxidant capacity of raw and frozen Brassica vegetables. Journal of Agricultural and Food Chemistry, 58(7), 4310-4321. PMid:20218674. http://dx.doi.org/10.1021/jf904306r.

Picoli, A. A., Faria, D. B., Jomori, M. L. L., \& Kluge, R. A. (2010). Avaliação de biorreguladores no metabolismo secundário de beterrabas inteiras e minimamente processadas. Bragantia, 69(4), 983-988. http://dx.doi.org/10.1590/S0006-87052010000400025.

Santos, M. D., \& Blatt, C. T. T. (1998). Teor de flavonoides e fenóis totais em folhas de Pyrostegia venusta Miers. de mata e de cerrado. Brazilian Journal of Botany, 21(2), 135-140. http://dx.doi.org/10.1590/ S0100-84041998000200004.

Scheibler, J., Ethur, E. M., Dal Bosco, S. M., \& Marchi, M. I. (2010). Quantificação de micronutrientes em vegetais submetidos a diferentes métodos de cocção para doente renal crônico. Conscientiae Saúde, 9(4), 549-555.

Schiozer, A. L., \& Barata, L. E. S. (2007). Estabilidade de corantes e pigmentos de origem vegetal. Revista Fitos, 3(2), 6-24. 
Singleton, V. L., Orthofer, R., \& Lamuela, R. M. (1999). Analysis of total phenols and other oxidation substrates and antioxidants by means of Folin-Ciocalteau reagent. Methods in Enzymology, 299, 152-178. http://dx.doi.org/10.1016/S0076-6879(99)99017-1.

Stintzing, F. C., Herbach, K. M., Mosshammer, M. R., Carle, R., Yi, W., Sellappan, S., Akoh, C. C., Bunch, R., \& Felker, P. (2005). Color, betalain pattern, and antioxidant properties of Cactus Pear (Opuntia spp.) clones. Journal of Agricultural and Food Chemistry, 53(2), 442451. PMid:15656686. http://dx.doi.org/10.1021/jf048751y.

Turkmen, N., Sari, F., \& Velioglu, I. S. (2005). The effect of cooking methods on total phenolics and antioxidant activity of select green vegetables. Food Chemistry, 93(4), 713-718. http://dx.doi.org/10.1016/j. foodchem.2004.12.038.

Vitti, M. C. D., Kluge, R. A., Yamamotto, L. K., \& Jacomino, A. P. (2003). Comportamento da beterraba minimamente processada em diferentes espessuras de corte. Horticultura Brasileira, 21(4), 623-626. http://dx.doi.org/10.1590/S0102-05362003000400009.

Volp, A. C. P., Renhe, I. R. T., \& Stringueta, P. C. (2009). Pigmentos naturais bioativos. Alimentos e Nutrição, 20(1), 157-166.

Zhang, D., \& Hamauzu, Y. (2004). Phenolics, ascorbic acid, carotenoids and antioxidant activity of broccoli and their changes during conventional and microwave cooking. Food Chemistry, 88(4), 503509. http://dx.doi.org/10.1016/j.foodchem.2004.01.065. 